J. Japan. Soc. Hort. Sci. 55(3) : 266-272. 1986.

\title{
Isolation and Spring Mobilization of Proteins in Citrus Trees (Citrus unshiu Marc. $)^{1}$
}

\author{
Tadashi Kato², Makoto Yamagata \\ and Sadao Tsukahara \\ Shikoku National Agricultural Experiment Station, \\ Zentsuji, Kagawa 765
}

\begin{abstract}
Summary
The proteins of the stem bark, stem wood and leaves of 23-year-old satsuma mandarin trees were separated into tris-soluble, alkaline-soluble and insoluble proteins. The tris-soluble proteins were separated further into five and six groups, using gel filtration and DEAE-cellulose column chromatography. Variations in the fractionated protein group were examined during spring and summer. Most of the proteins isolated, contributed to nitrogen mobilization in varying degrees. In leaves a protein of molecular weight of about 55, 000 showed the largest decrease. Amino acid analysis of six protein groups from the tris-soluble proteins of the bark showed no difference in their amino acid composition. The nitrogen storage function of proteins is discussed.
\end{abstract}

\section{Introduction}

One of characteristics of nitrogen nutrition of fruit trees is the accumulation of high amounts of nitrogen during the fall, and its use for new shoot development in the following spring $(5,9)$. Storage proteins in fruit trees have received little attention until quite recently, although in apple trees there is a fund of information emerging. Although the presence of an arginine-rich protein has been reported in apple shoot bark $(8,10)$, storage proteins have only been partially characterized. In citrus trees, not only the bark and wood(4), but also leaves $(4,7)$ are main organs of nitrogen storage, and the main form of storage nitrogen is the protein nitrogen found in every organ (4). Other information concerning storage proteins is limited in citrus trees.

In this study, the mobilization of isolated proteins during the spring and summer growth periods and their amino acid composition were examined.

\section{Materials and Methods}

\section{Plant materials}

1 Received for publication November 19, 1985

2 Present address : National Grassland Research Institute, Nishinasuno, Tochigi 329-27
One-year-old leaves, bark and wood of 2year-old-stems were sampled from 23-yearold satsuma mandarin trees (Citrus unshiu Marc.) grafted on Poncirus trifoliata grown in concrete vessels $(2 \mathrm{~m} \times 2 \mathrm{~m} \times 1.2 \mathrm{~m}$ depth). Nitrogenous fertilizer was applied in mid March (243 g N/tree), in mid June (82 g $\mathrm{N} /$ tree) and in mid November (135 $\mathrm{g} \mathrm{N} /$ tree). All samples were lyophilized and powdered with a Heiko-vibrating mill. Powdered samples were stored in a refrigerator at $5^{\circ} \mathrm{C}$ until analysis.

\section{Extraction of proteins}

One gram of leaf, bark and wood samples was routinely used for analysis. These sam ples were treated with acetone and then with diethyl ether. The treated samples were extracted in $10 \mathrm{ml}$ of $0.1 \mathrm{M}$ Tris (tris (hydroxymethyl) aminomethane) buffer con taining $0.4 \mathrm{M} \mathrm{NaCl}$ ( $\mathrm{pH} 8.0$ ). Extractions were carried out using a Kinematica polytron in a ice bath. The homogenized sample was centrifuged at $20,000 \mathrm{~g}$ for $10 \mathrm{~min}$ and the supernatant collected. The residue was ex tracted a further twice, and the supernatants combined (Tris-soluble). The residue was then extracted in $10 \mathrm{ml}$ of $0.2 \mathrm{M} \mathrm{NaOH}$ solution three times, and the supernatants 
were again combined (alkaline-soluble). Protein in these extracts was assayed by the method of Bradford(1) using bovine serum albumin as a standard. The insoluble residue was digested by the Kjeldahl method and nitrogen content determined.

\section{Separation of low molecular compounds}

Tris-soluble extracts were dialyzed against $5 \mathrm{mM}$ sodium borate buffer (pH 9.5) for DEAE-cellulose(diethyl aminoethyl cellulose) column chromatography, and against $0.1 \mathrm{M}$ Tris buffer containing $0.4 \mathrm{M} \mathrm{NaCl}$ ( $\mathrm{pH} \mathrm{8.0)}$ for Sephacryl S-300 column chromatography for $24 \mathrm{~h}$ with several changes of buffer.

Fractionation by DEAE-cellulose column

The dialyzed extract was fractionated on a $2 \mathrm{~cm}$ (ID) $\times 18 \mathrm{~cm}$ (L) DEAE-cellulose column which had been pre-equilibrated with the sodium borate buffer ( $\mathrm{pH}$ 9.5). Protein fractions were eluted by a stepwise gradient of $0.01,0.05,0.1,0.2$ and $0.3 \mathrm{M} \mathrm{NaCl}$ and $0.5 \mathrm{M} \mathrm{NaOH}$. Ten gram fractions were collected and assayed for protein.

Fractionation by Sephacryl S-300 column

The dialyzed extract was fractionated on a $2.2 \mathrm{~cm}$ (ID) $\times 60 \mathrm{~cm}$ (L) Sephacryl S-300 column, which had been pre-equilibrated with $0.1 \mathrm{M}$ Tris buffer containing $0.4 \mathrm{M} \mathrm{NaCl}$, with The Tris buffer containing $0.4 \mathrm{M} \mathrm{NaCl}$. Five-milliliter fractions were collected and assayed for protein.

Amino acid analysis of the fractionated pro:eins

Tris-soluble proteins of the bark sampled on the 27 th of March were separated into six groups on a DEAE-cellulose colum. Proteins in the effluent were precipitated by making up to $5 \%$ with trichloroacetic acid.

Table 1. Amounts of Tris-soluble, alkaline-soluble and insoluble proteins in the bark, wood, and leaves sampled on March 27 (protein : mg/g Dw).

\begin{tabular}{lccc} 
Component & \multicolumn{3}{c}{ Organ } \\
& Bark & Wood & Leaf \\
\hline Tris-soluble & 27.5 & 6.62 & 38.6 \\
Alkaline-soluble & 28.9 & 8.50 & 35.9 \\
Insoluble & 25.1 & 15.8 & 63.4 \\
\hline Total & 81.5 & 30.92 & 137.9 \\
\hline
\end{tabular}

z Using conversion factor (6.25).
After centrifugation, the protein precipitate was dispersed in $5 \mathrm{ml}$ of $6 \mathrm{M} \mathrm{HCl}$ and taken up into a glass ampule. Protein hydrolysis was performed under $\mathrm{N}_{2}$ gas for $24 \mathrm{~h}$ at $110^{\circ} \mathrm{C}$. Amino acids in the hydrolyzate were determined by an amino acid autoanalyzer.

\section{Results and Discussion}

Tris-soluble, alkaline-soluble and insoluble proteins

The composition of Tris-soluble, alkalinesoluble and insoluble proteins depended on the organ (Table 1). The bark contained each protein fraction in almost equal proportions. The wood and leaf showed high levels of the insoluble protein fraction, amounting to about twice the other fraction. Moreno and Garcia-Martinez(7) reported that the aqueous soluble protein was the major fraction $(47 \sim 67 \%)$ of the total protein of navel orange leaves. We found that the major fraction (about 50\%) was extracted
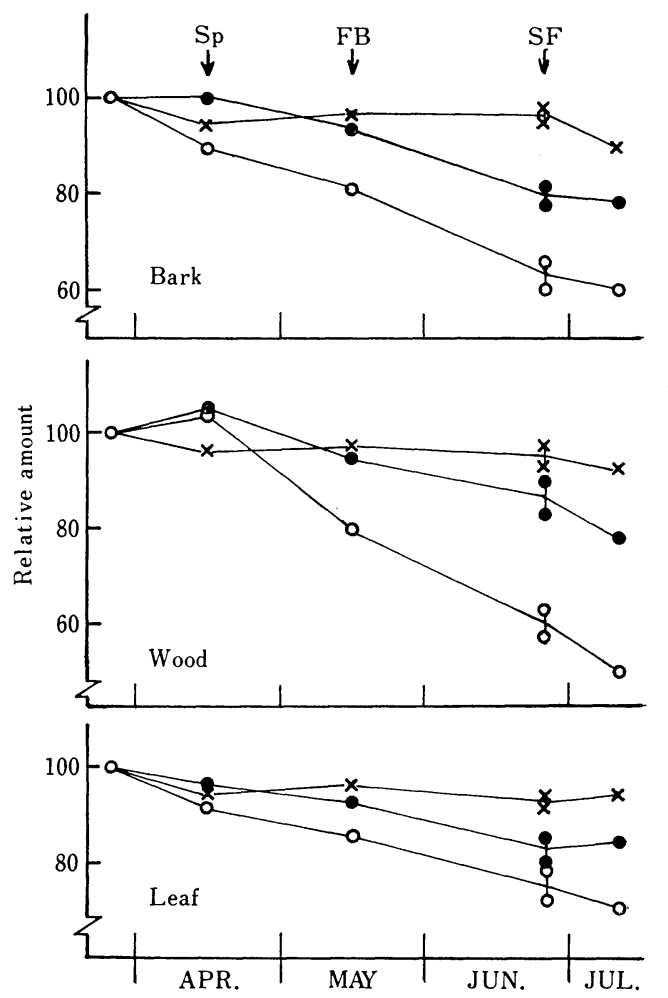

Fig. 1. Changes in Tris-soluble (O), alkaline-soluble $(\bullet)$ and insoluble $(x)$ proteins from the bark, wood and leaves during spring and summer. Sp ; sprouting, FB; full bloom, SF ; summer flush. 


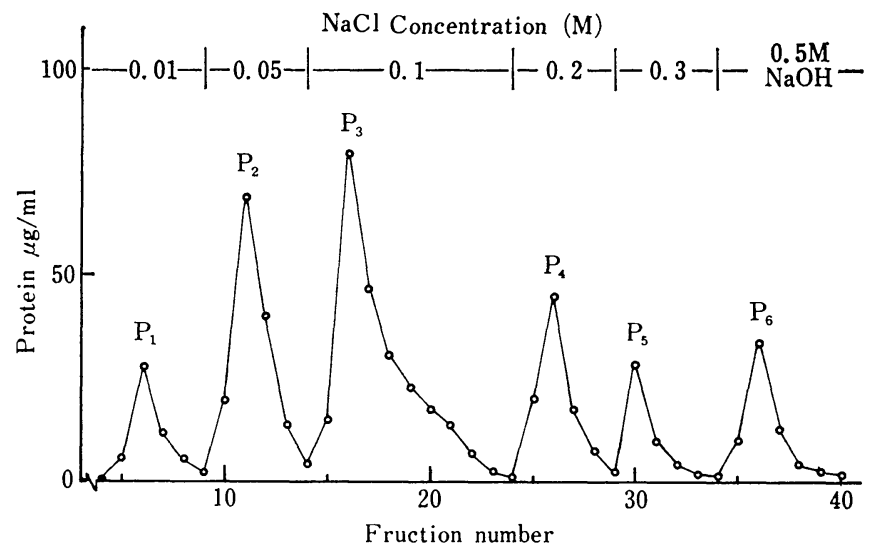

Fig. 2. A DEAE-cellulose elution profile of Tris-soluble protein fracions from the stem bark sampled on March 27. The column was eluted using a stepwise gradient of $0.01,0.05,0.1,0.2,0.3 \mathrm{M} \mathrm{NaCl}$, and $0.5 \mathrm{M} \mathrm{NaOH}$, eluting $P_{1}$, $\mathrm{P}_{2}, \mathrm{P}_{3}, \mathrm{P}_{4}, \mathrm{P}_{5}$ and $\mathrm{P}_{6}$ proteins in that order.

Table 2. Amounts of fractionated proteins in Trissoluble extracts by a DEAE-cellulose column from the stem bark, wood, and leaves sampled on March 27. For the $\mathrm{P}_{1}, \mathrm{P}_{2}, \mathrm{P}_{3}, \mathrm{P}_{4}, \mathrm{P}_{5}$ and $\mathrm{P}_{6}$ proteins, see Fig. 2.

\begin{tabular}{|c|c|c|c|c|c|c|}
\hline \multirow{2}{*}{ Organ } & & & \multicolumn{2}{|c|}{ Protein (mg/g Dw) } & \multirow[b]{2}{*}{$\mathrm{P}_{5}$} & \multirow[b]{2}{*}{$\mathrm{P}_{6}$} \\
\hline & $\mathrm{P}_{1}$ & $\mathrm{P}_{2}$ & $\mathrm{P}_{3}$ & $\mathrm{P}_{4}$ & & \\
\hline Bark & 2.06 & 7.20 & 9.62 & 4.45 & 2.02 & 2.12 \\
\hline Wood & 0.68 & 2. 17 & 1.80 & 0.68 & 0.38 & 0.88 \\
\hline Leaf & 1.95 & 5.48 & 14.1 & 6.88 & 2.95 & 7.25 \\
\hline
\end{tabular}

from fresh leaves as the water-soluble protein, and further that the freezing treatment at $-20^{\circ} \mathrm{C}$ for one week or the lyophilizing treatment reduced the water-soluble proteins by about $10 \%$ or $30 \%$, respectively (unpublished data). Probably most of the watersoluble proteins are Tris-soluble, although lower values for Tris-soluble proteins were obtained here. A part of the water-soluble protein may have become insoluble during lyophilization, powdering and cold storage processes prior to analysis in this experiment.

The most marked decrease during the regrowth period was found in the Tris-soluble proteins, followed by the alkaline-soluble proteins, regardless of organ. The insoluble proteins contributed slightly to the nitrogen mobilization (Fig. 1). This indicates that the more easily soluble proteins contribute more to nitrogen mobilizarion.

Fractionation by DEAE-cellulose

The Tris-soluble proteins from the bark,

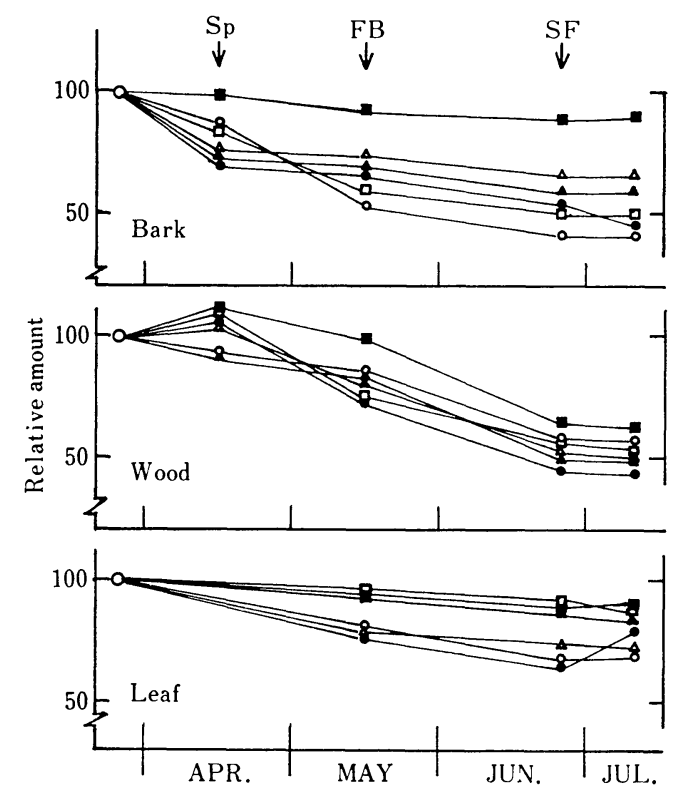

Fig. 3. Changes in relative levels of Tris-soluble protein fractions separated by a DEAE-cellulose column during spring and summer. For $P_{1}(O)$, $\mathrm{P}_{2}(\bullet), \mathrm{P}_{3}(\Delta), \mathrm{P}_{4}(\boldsymbol{\Delta}), \mathrm{P}_{5}(\square)$ and $\mathrm{P}_{6}(\boldsymbol{\square})$ proteins, see Fig. 2, See Fig. 1 for other details.

wood and leaves were separated into six protein groups on a DEAE-cellulose column (Fig. 2). The composition of protein groups depended on the organ (Table 2). In order to find out which proteins contributed greatest to nitrogen mobilization, separated protein groups were measured during the spring 


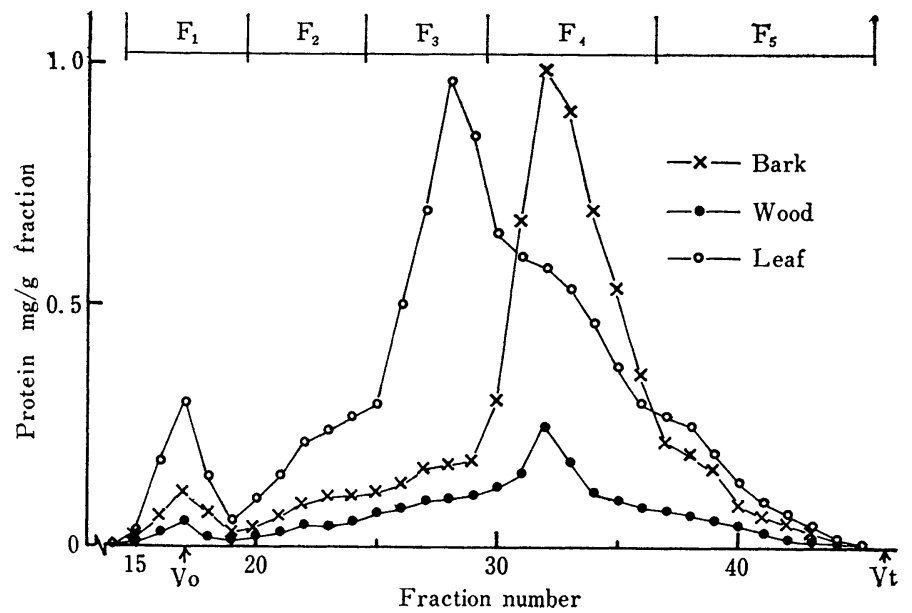

Fig. 4. Gel (Sephacryl S-300) filtration patterns of Tris-soluble proteins from the stem bark, stem wood and leaves sampled on March 27. $F_{1}, F_{2}, F_{3}, F_{4}$ and $F_{5}$ proteins were collected from fraction numbers 15-19,20-24, 25-29, 30-36 and 37-45, respectively.

Table 3. Amounts of fractionated proteins in Trissoluble extracts by a S-300 column from the bark, wood, and leaves sampled on March 27. For $F_{1}, F_{2}, F_{3}, F_{4}$ and $F_{5}$ proteins, see Fig. 4 .

\begin{tabular}{lccccc}
\hline \multirow{2}{*}{ Organ } & \multicolumn{5}{c}{ protein $(\mathrm{mg} / \mathrm{g} \mathrm{DW})$} \\
\cline { 2 - 6 } & $\mathrm{F}_{1}$ & $\mathrm{~F}_{2}$ & $\mathrm{~F}_{3}$ & $\mathrm{~F}_{4}$ & $\mathrm{~F}_{5}$ \\
\hline Bark & 0.83 & 0.95 & 2.90 & 19.3 & 3.48 \\
Wood & 0.28 & 0.45 & 1.11 & 3.57 & 1.17 \\
Leaf & 2.73 & 3.68 & 13.7 & 13.9 & 4.59 \\
\hline
\end{tabular}

and summer growth periods (Fig. 3). All protein groups in all organs decreased in varying degrees during the sprouting and summer flush periods.

Using a DEAE-cellulose column, O'Kennedy and Titus(8) separated the total extractable proteins of apple bark in to three groups, and found that the decrease in protein groups differed greatly in the first week after the start of regrowth, and at further 2 weeks later every protein group had decreased by $80 \%$ or more. In citrus, there was no specific protein group which decreased as much as the apple bark protein.

Fractionation by gel filtration

The proteins eluted from the Sephacryl S300 column were arbitrarily divided into five groups of protein of differing molecular weights: F 1, >300, $000 ; \mathrm{F} 2,300,000-160,000$; F 3, 160, 000-50, 000 ; F 4, 50, 000-10, 000 ; F $5, \quad<10,000$ (Fig. 4). The gel filtration profile of the Tris-soluble proteins was
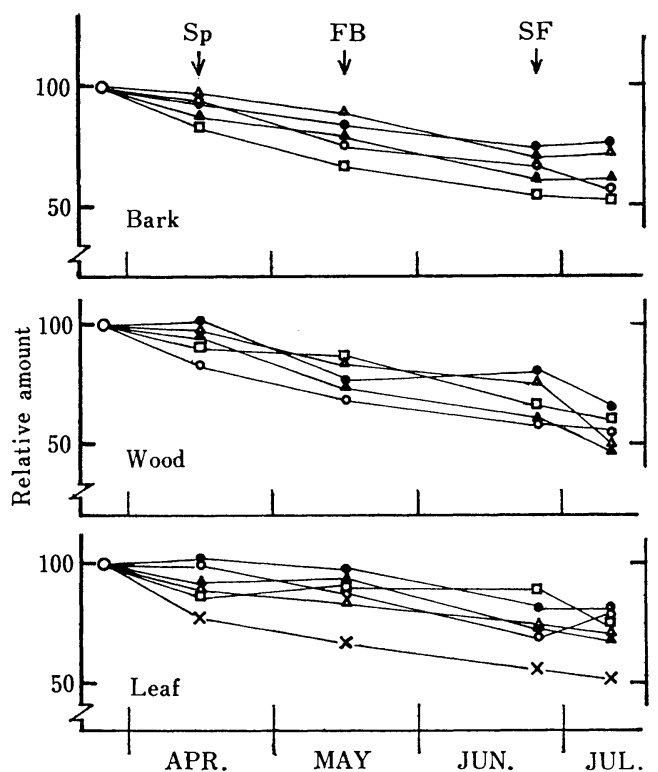

Fig. 5. Changes in relative levels of Tris-soluble protein fractions separated by a Sephacryl S-300 column during spring and summer. For $F_{1}(O)$, $F_{2}(\bullet), F_{3}(\Delta), F_{4}(\Delta)$ and $F_{5}(\square)$ proteins, see Fig. 4. The protein $(X)$ was eluted at the fruction [numbers 28 (MW : about 55000). See Fig. 1 for other details.

dependent on the organ. F 4 proteins were most abundant in every organ. F 3 proteins were adundant in leaves (Table 3). All these proteins decreased in varying degrees during the spring and summer growth periods. 
Moreno and Garcia-Martinez(7) examined the annual cycle of water-soluble proteins in Washington navel orange leaves by SDSPAGE (sodium dodecylsulfate-polyacrylamide gel electrophoresis) technique, and found that most of the foliar proteins decreased from February to June followed by a quick recovery to the initial protein content during July (from the end of the spring growth to the beginning of the summer growth). They also found that the most marked decrease was in a protein of molecular weight about 55,000, which is thought to be the large subunit of RuBP (ribulose-1,5biphosphate) carboxylase/oxygenase. Marked hydrolysis of this enzyme during autumnal senescence has been found in apple leaves(3). In Satsuma mandarin leaves, the greatest decrease was also found in a protein of molecular weight about 55,000. However, any recovery of the initial protein content in satsuma mandarin leaves was not observed during the period tested.

These different patterns of protein mobilization between different citrus cultivar leaves may be due to a difference in the expression of data, i. e., the question of the absolute amount per leaf or on a concentration bases. Wallace et al. (11) obtained data suggetsing that more clear recoveries of total protein content in Washington navel orange leaves are detected between the end of spring and the beginning of summer growth when the data are expressed on a leaf basis rather than on a concentration bases. To examine whether any recovery of proteins in old leaves occurs between the spring growth and the summer growth in satsuma mandarin trees, and to examine further the nitrogen mobilization in leaves, the data should be expressed on a leaf basis.

Amino acid composition of fractionated proteins

Amino acid analysis indicated that there was no difference in the amino acid composi tion of the six protein groups fractionated by the DEAE-cellulose column (Table 4). Tromp and Ovaa(10) presented data suggesting the presence of proteins with a high arginine content in apple shoot bark.
Table 4. Amino acid composition of fractionated proteins in Tris-soluble extracts by a DEAEcellulose column from the bark sampled on March 27.

\begin{tabular}{|c|c|c|c|c|c|c|}
\hline & \multicolumn{6}{|c|}{ Molar Composition (\%) } \\
\hline & $\mathrm{P}_{1}$ & $\mathrm{P}_{2}$ & $\mathrm{P}_{3}$ & $\mathrm{P}_{4}$ & $\mathrm{P}_{5}$ & $\mathrm{P}_{6}$ \\
\hline $\operatorname{Asp}(x)^{y}$ & 14.3 & 13.3 & 12.4 & 12.6 & 12.0 & 12.0 \\
\hline Hypro & nd & nd & nd & nd & + & + \\
\hline Thr & 5.8 & 5.9 & 5.0 & 5.1 & 5.8 & 5.9 \\
\hline Ser & 7.8 & 5.7 & 4.0 & 4. 1 & 5.1 & 3.8 \\
\hline $\operatorname{Glu}(x)^{y}$ & 9.1 & 9.1 & 10.2 & 10.5 & 11.5 & 10.3 \\
\hline Pro & 6.2 & 5.7 & 6.9 & 6.7 & 5.8 & 5.3 \\
\hline Gly & 11.7 & 10.2 & 12.4 & 11.9 & 11.3 & 9.3 \\
\hline $\mathrm{Ala}$ & 8.1 & 7.2 & 8.2 & 8.0 & 7.8 & 8.0 \\
\hline Val & 6.5 & 7.8 & 4.5 & $4 \triangleleft 9$ & 5.5 & 6.9 \\
\hline Cys & + & 0.9 & 2.0 & 1.8 & 0.8 & + \\
\hline Met & + & 0.3 & + & 0.5 & 0.3 & 0.7 \\
\hline Ile & 4.9 & 4.8 & 5.3 & 5.1 & 5.2 & 5.6 \\
\hline Leu & 7.8 & 8.5 & 7.1 & 7.4 & 8.1 & 9.3 \\
\hline Tyr & 1.3 & 3.3 & 4.9 & 4.5 & 3.7 & 3.4 \\
\hline Phe & 5.5 & 5.0 & 5.8 & 5.5 & 5.4 & 5.2 \\
\hline Lys & 5.2 & 4.5 & 4.1 & 4.5 & 4.9 & 6.4 \\
\hline $\mathrm{His}$ & 0.3 & 1.5 & 1.4 & 1.6 & 1.7 & 3.0 \\
\hline Arg & 5.5 & 6.4 & 5.7 & 5.3 & 5.1 & 4.9 \\
\hline Total & 100 & 100 & 100 & 100 & 100 & 100 \\
\hline $\mathrm{PRAN}^{\mathrm{z}}$ & 15 & 95 & 94 & 98 & 96 & 29 \\
\hline
\end{tabular}

$z$ Percentage recovery as amino acid nitrogen in the total Kieldahl nitrgen.

y including its amide.

nd : not detected.

$+:$ trace amount.

O'Kennedy and Titus(8) separated the apple bark protein into three groups using DEAEcellulose column chromatography and found a marked difference in the arginine content of these protein groups. On the contrary, Kato et al. (4) suggested the absence of arginine-rich proteins in mature citrus trees with a high level of nitrogen, although this protein is the principal storage form of ni trogen. Further, Kato et al. (6) found that citrus trees fed with ${ }^{15} \mathrm{~N}$-nitrate produced no protein characterized by a high ${ }^{15} \mathrm{~N}$-arginine content during autumn. It is unlikely that citrus tissues synthesize specific proteins characterized by a high arginine content, even when they receive a large amount of nitrogen.

$\mathrm{P}_{2}-\mathrm{P}_{5}$ fraction nitrogen was recovered mostly as amino acid nitrogen, but $\mathrm{P}_{1}$ and $\mathrm{P}_{6}$ fractions were composed largely of unknown 
nitrogenous compounds other than amino acids (Table 4). The information about these unknown compounds is limited.

In seeds, storage proteins other than enzymes are found, and often exist as discrete protain bodies. In apple bark, the presence of protein-rich membranous capsules has been reported(2). Even though this finding suggests the presence of protein body like structures, the presence of a protein body functioning as the storage protein in seeds has not yet been established in any species of fruit trees. It is well known that protein nitrogen is accumulated during fall and winter and decreases during the growth period in fruit trees $(5,9)$. However, there is no clear definition of what the storage proteins in plant tissues other than seeds are.

O'Kennedy and Titus(8) proposed a working definition of a storage protein in apple shoot bark. They used two criteria for these proteins : (1) they are prominent in dormant shoots and may contain a high proportion of basic amino acids, such as arginine, and(2) they disappear as growth is resumed(cf. 9). Considering the data obtained here, citrus tissues are unlikely to have the storage proteins which satisfy not only the first, but also the second criterion. Consequently, whether these criteria will apply to citrus proteins is doubtful.

In this paper, therefore, proteins which decreased during the spring growth were discussed as storage proteins. These proteins may have a function as an enzyme, for example, RuBP carboxylase/oxygenase is intimately concerned with the fixiation of $\mathrm{CO}_{2}$, while, at the same time, it probably functions as a nitrogen reservoir for spring and summer growth(7)

\section{Literature Cited}

1. BRADFORD, M. M. 1976. A rapid and sensi- tive method for the quantitation of microgram quantities of protein utilizing the prin ciple of protein-dye binding. Anal. Biochem. $72: 248-254$.

2. HENNERTY, M. J., B. T. O'KENNEDY and J. S. TiTus. 1980. ¿Conservation and reutilization of bark proteins in apple trees. p. 369377. In : D. ATKINSON, J. E. JACKSON, R. O. Sharples, W. M. WALler(eds.) Mineral nutri tion of fruit trees. Butterworths, London.

3. KAN, S. M. and J. S. TITUS. 1980. Qualita tive and quantitative changes in nitrogenous compounds in senescing leaf and bark tissues of the apple. Physiol. Plant. $50: 285-290$.

4. KATO, T., M. YAmagATA and S. TSUKAhara. 1984. Storage forms and reservoirs of nitrogen used for new shoot development in Satsuma mandarin trees. J. Japan. Soc. Hort. Sci. 52 : 393-398 (Japanese with English summary).

5. KATO, T. 1986. Nitrogen metabolism and utilization in Citrus. Hort. Rev. $8: 181-216$.

6. KATO, T., M. YAmagata and S. TSUKAHARA. 1986. A trial of ${ }^{13} \mathrm{C}$ and ${ }^{15} \mathrm{~N}$-double labelling tehnique for analysis of carbon and nitrogen storage in a young Satsuma mandarin tree. Bull. Shikoku Natl. Agric. Exp. Stn. (Japanese with English summary). (in press)

7. Moreno, J. and J.!L. GARCIA-MARTINEZ. 1984. Nitrogen accumulation and mobilization in Citrus leaves throughout the annual cycle. Physiol. Plant. $61: 429-434$.

8. O'KenNEDY, B. T. and J. S. TITUS. 1979. Isolation and mobilization of storage proteins from apple shoot bark. Physiol. Plant. 45 : $419-424$.

9. Titus, J. S. and S. M. Kang. 1982. Nitrogen metabolism, translocation, and recycling in apple trees. Hort. Rev. $4: 204-246$.

10. TROMP, J. and J. C. OVAA. 1973. Spring mobilization of protein nitrogen in apple bark. Physiol. Plant. $29: 1-5$.

11. Wallace, A., Z. I. ZIDAN, R. T. Muller and C. P. NORTH. 1954. Translocation of nitrogen in citrus trees. Proc. Amer. Soc. Hort. Sci. $64: 87-104$. 


\title{
ウンシュウミカン樹におけるたんぱく質の 分別と春季に拈ける消長 \\ 加藤忠司 ${ }^{1} \cdot$ 山県真人 $\cdot$ 塚原貞雄 \\ 四国農業試験場 765 香川県善通寺市
}

\begin{abstract}
摘要
23 年生ウンシュウミカン樹の葉, 2 年生枝の皮質部 及び木質部より $0.1 \mathrm{M}$ トリス緩衝液 $(\mathrm{pH} \mathrm{8.0)}$ 可溶及 び $0.2 \mathrm{M}$ 水酸化ナトリウム可溶たんぱく質を抽出した. またトリス緩衝液可溶たんぱく質について, DEAE七ル ロースカラムクロマトグラフィー及びゲルろ過法によっ てそれぞれ 6 種類及び 5 種類のたんぱく質画分に分別し た.これら各種たんぱく質画分の消長を 3 月から 7 月に かけて調べた.

各器官より得られた可溶たんぱく質及び分別たんぱく 質のほとんどがこの時期, 程度に差があるものの明らか

1 現在 草地試験場牧草部

に減少した。ただ葉においては，分子量約55,000のたん ぱく質の減少割合が他に比べて大であった，皮質部より トリス緩衝液で抽出し，DEAEセルロースカラムで分別 した 6 種類のたんぱく質画分のアミノ酸組成には明白な 違いはなく, 特異なアミノ酸組成のたんぱく質は存在し なかった。

これらの結果から，ミカン樹の各種たんぱく質のほと んどは程度に差があるが，窒素貯蔵の役割を持つと考兄 られる、また葉中窒素の貯蔵的役割を論ずる場合, デー 夕は濃度単位でなく、葉 1 枚当たりで扱う必要があると 考えられた。
\end{abstract}

